\title{
Elk forage utilization within rested units of rest-rotation grazing systems
}

\author{
SCOTT J. WERNER AND PHILIP J. URNESS
}

Authors are graduate student and late professor of Range Science, Rangeland Resources Dept., Utah State University, Logan, Ut. 84322-5230.

\section{Abstract}

Elk (Cervus elaphus) have been repeatedly observed to prefer rested units within rest-rotation grazing systems. Given the logistical and financial investments associated with the maintenance of these systems, elk herbivory within rested units is a potential source of conflict. Elk forage utilization was determined during the summers of 1994 and $\mathbf{1 9 9 5}$ at the forest-grassland ecotone of 3 rest-rotation grazing allotments in south-central Utah's Fishlake National Forest. Average phytomass within areas protected from and subjected to elk herbivory was not statistically different in June and August 1994. Average phytomass within caged areas was greater $(P<0.20)$ than that within areas subjected to elk use in 2 of 3 rested units in June-July 1995 (14.1 and 35.6\% utilization) and August 1995 (34.7 and 42.0\% utilization). June-to-August forage regrowth, however, was 31.3 and 33.0\% greater in 1995 than in 1994 within caged and uncaged areas, respectively.

Key Words: cattle, herbivory, forage regrowth

Although elk (Cervus elaphus) herds were common in northern and south-central Utah prior to and during European settlement, unrestricted elk hunting facilitated the extirpation of most populations by the early 20th century. From 1912 to 1925 , elk from Yellowstone National Park were transplanted to several areas within Utah, including the Fishlake National Forest. In 1925, the Utah Board of Elk Control authorized the first elk hunting season in response to "deteriorating range conditions and agricultural damage problems" and to "cope with problems [associated with] the rapidly increasing elk herds" (Utah Division of Wildlife Resources 1994). Harvest data suggest elk populations increased consistently within Utah since 1931.

Rest-rotation grazing systems were developed in the late 1950's to counteract the harmful effects of selective herbivory (Hormay and Evanko 1958). These systems were proposed to restore plant vigor, and promote seed production and seedling

This study was supported in part by Utah's Division of Wildlife Resources (Federal Aid Project W-105-R) and the Fishlake National Forest (Richfield District). We thank DWR wildlife biologist Norm Bowden and FNF employees Bob Campbell and Vince Pace for their involvement. We also thank E.W. Bork and F.D. Provenza for their review of a previous draft of this manuscript., and Dr. Juan Villalba (Rangeland Resources Dept., Utah State Univ., Logan, Ut 84322 5230) for his assistance in translating our abstract.

Manuscript accepted 12 Jan. 1997.

\section{Resumen}

Se ha observado repetidamente que ciervos (Cervus elaphus) prefieren unidades de descanso dentro de los sistemas de pastoreo rotativos. Dada la inversión logistica y financiera asociada al mantenimiento de estos sistemas, la herbivoria por parte de ciervos dentro de las unidades de descanso es una fuente potencial de conflicto. Durante los veranos de 1994 y 1995 se determinó la utilización de forraje por parte de ciervos en el ecoton bosque-graminea en 3 establecimientos de pastoreo rotativo ubicados en la parte surcentral de Bosque Nacional Fishlake en Utah. En junio y Agosto de 1994, el promedio de fitomasa dentro de las areas protegidas o de las sometidas a herbivoria por parte de ciervos no resultó significativamente diferente. El promedio de fitomasa dentro de areas de clausura fué mayor $(P<0.20)$ que el promedio dentro de las areas sometidas al uso por parte de ciervos en 2 de 3 unidades de descanso en Junio-Julio de 1995 (14.1 y 35.6\% de utilización) y en Agosto de 1995 (34.7 y 42.0\% de utilización). No obstante, el rebrote de forraje de Junio a Agosto fué 31.3 y 33.0\% mayor en 1995 que en 1994 dentro de areas de clausura o sin clausura, respectivamente.

establishment via periodic, season-long rest from cattle (Bos spp.) grazing (Hormay and Talbot 1961). Nonetheless, several investigators have noted elk preference for rested units within restrotaion grazing systems in Montana (Knowles and Campbell 1981, Frisina 1992), Idaho (Yeo et al. 1993), and Utah (Clegg 1994). Given the potential overlap of elk and cattle summer range diets (Mackie 1978), Hormay's principles regarding the restoration of plant vigor via rest may be negated by elk herbivory within rested units.

Because of the time and financial investments incurred by establishing a rest-rotation grazing system and the apparent increase in Utah's elk populations, this research was designed to determine (1) the degree of elk forage utilization within rested units; and (2) the association between elk forage utilization and forage regrowth.

\section{Study Areas}

This study was conducted on 6 grazing units (i.e., pastures) within 3 rest-rotation grazing allotments on the Richfield Ranger District of the Fishlake National Forest (Sevier and Piute counties, Utah). The Quitchupah allotment is about 10,350 ha and is a 4-unit, 4-treatment system. The Willow Creek (ca 6,475 ha) and 
Table 1. Graxing schedules for sampled grazing units during the 1994 and 1995 grazing seasons.

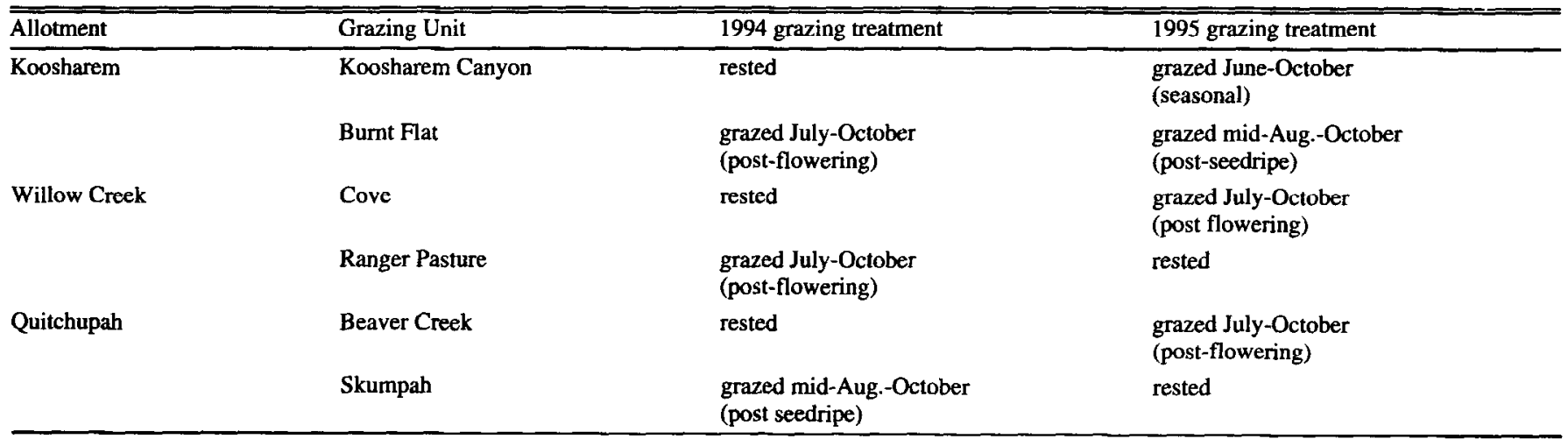

Koosharem (ca 14,250 ha) allotments are 5- and 6-unit, 4-treatment systems, respectively. All allotments are grazed by cattle from June to October.

Grazing treatments include grazing after flowering and seedripening of dominant forage species, seasonal grazing (from June to October), and season-long rest (Table 1). Elk forage utilizaton within the Koosharem allotment was estimated for the Koosharem Canyon and Burnt Flat grazing units. The Burnt Flat unit was considered rested during the 1995 grazing season as all sampling was concluded prior to cattle entry. The Cove and Ranger Pasture units were sampled within the Willow Creek allotment, and the Beaver Creek and Skumpah units were sampled within Quitchupah allotment (Table 1).

The dominant forest community types within the Fishlake National Forest include aspen (Populus tremuloides Michx.; Latin vegetation names from Welsh et al. 1993) and ross sedge (Carex rossii F. Boott) stands, occasionally codominated by subalpine fir (Abies lasiocarpa [Hook.] Nutt.) and mountain snowberry (Symphoricarpos oreophilus Gray) in the overstory and shrub layers, respectively (Mueggler 1988). Parent materials associated with the Koosharem allotment are mainly from the Dry Hollow latite formation and Bullion Canyon volcanics, and vegetation is dominated by sagebrush (Artemisia spp. L.), aspen, Gambel oak (Quercus gambelii Nutt.), and various meadow types. While some grasses and shrubs exist in tree interspaces, most of the vegetation within the Willow Creek and Quichupah grazing allotments is dominated by aspen communities (R.K. Tew, J.T. Lott, and T.M. Bliss, unpublished report, 1988). The Willow Creek allotment is further described by Julander and Jeffery (1964). The soils, vegetational communities, and land type associations for the Koosharem, Willow Creek, and Quichupah allotments have been described in detail by Werner (1996).

\section{Methods}

\section{Elk Forage Utilization and Forage Regrowth}

Elk forage utilization was estimated by comparing the aboveground phytomass of grasses and forbs clipped within and outside each cage (i.e., the paired cage method; Bonhan 1989). Averages of (caged-uncaged) phytomass differences and these differences relative to forage availability (i.e., percent utilization $=[$ [cageduncaged]/caged] $\times 100$ ) were used to quantify the degree of elk herbivory within rested units.

By measuring phytomass differences between caged and uncaged microplots, forage utilization estimates were assumed to be attributable to elk herbivory. This assumption was supported using a 1-m wide belt transect connecting paired plots to quantify the fecal remains of mammalian herbivores. Based on pellet

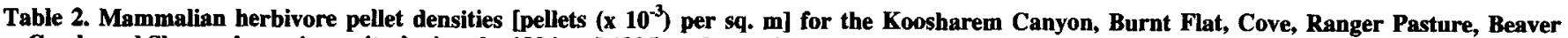
Creek, and Skumpah grazing units during the 1994 and 1995 cattle-grazing seasons.

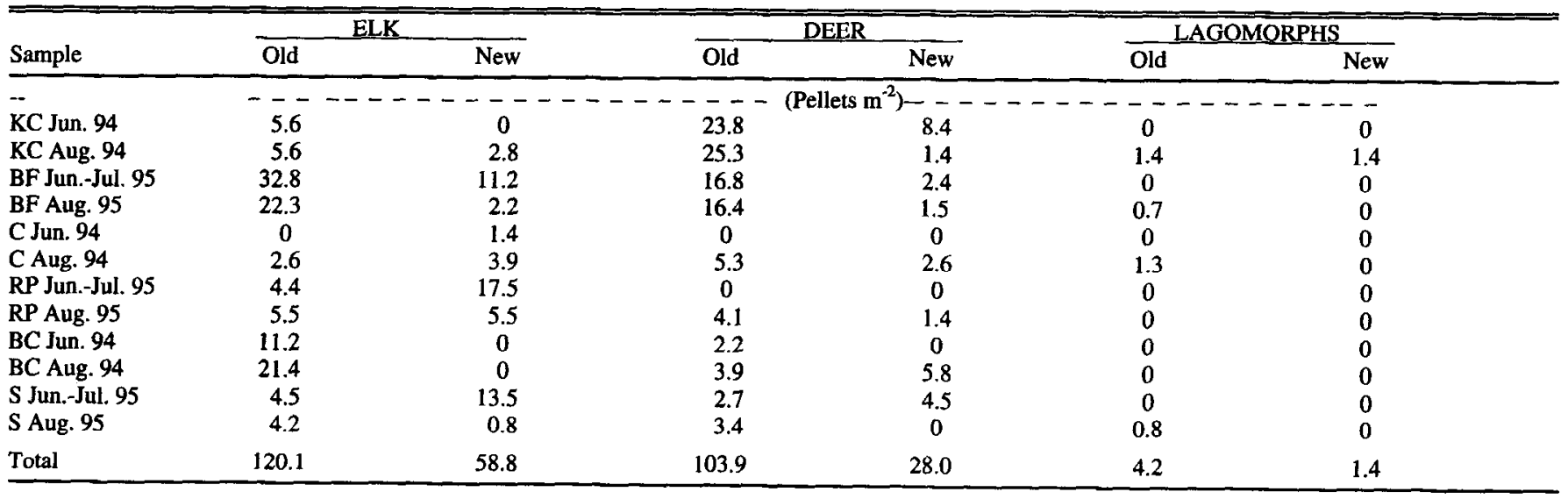


group densities, elk were found to be the most abundant, freeranging herbivore adjacent to plots prior to sampling (Table 2).

The sampling strata investigated in this study were defined as the 50-m interface, or ecotone, between forest and grassland vegetational communities. Twenty plots were established between 2,700 and $3,050 \mathrm{~m}(9,000$ to 10,000 feet $)$ elevation within 2 units for each of 3 grazing allotments. All data were collected during periods of non-use by livestock (i.e., prior to cattle grazing or during years of rest). Plots were sampled in June 1994 and June-July 1995 for all 6 grazing units and in August of 1994 and 1995 for the 3 units rested from cattle herbivory during the sampling year.

Within rested units, a plot consisted of 2 cages (each of $0.5 \mathrm{~m}^{2}$ area) and their 2 uncaged counterparts. This allowed for sampling within each plot in both the June--July and August sampling periods. Forage regrowth within rested units was determined by comparing the phytomass of caged and uncaged microplots clipped in June-July and reclipped in August.

Samples were clipped (to a $1-\mathrm{cm}$ stubble height) from a $0.4 \mathrm{~m}^{2}$ microplot placed within caged and uncaged areas. Cages were returned after clipping and samples were dried (at $60^{\circ} \mathrm{C}$ for 12 hours) and weighed to the nearest gram. Cages were moved a minimal distance between the 1994 and 1995 growing seasons to avoid floral 'stagnation' (Tueller and Tower 1979).

\section{Data Analyses}

Student's $t$ tests were used to examine the differences between means of (1) caged and uncaged above-ground phytomass; (2) spring phytomass during 1994 versus 1995; (3) phytomass differences in June 1994 verses June-July 1995; and (4) caged and uncaged forage regrowth. All differences discussed are statistically significant at the $5 \%$ level of probability unless otherwise noted. Nonlinear (i.e., polynomial) regression analyses were used to determine the association between average phytomass differences and forage regrowth.

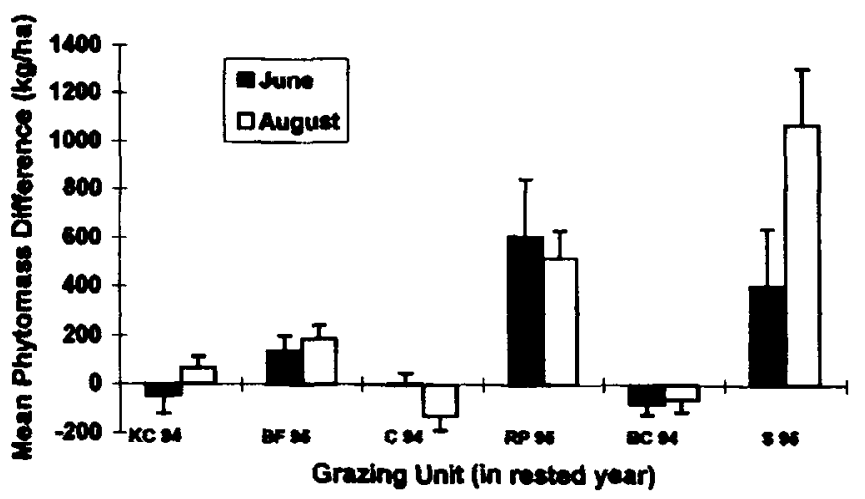

Fig. 1. Average phytomass differences ( \pm SEM) between areas protected from and subjected to elk herbivory within rested units $(n=$ 3) during the 1994 and 1995 cattle-grazing seasons. Phytomass differences were estimated within the Koosharem (KC $=$ Kousharem Canyon grazing unit; BF = Burnt Flat), Willow Creek (C = Cove; $\mathbf{R P}=$ Ranger Pasture), and Quichupah (BC = Beaver Creek; $\mathbf{S}=$ Skumpah) allotments in the Fishlake National Forest (Richfield District).

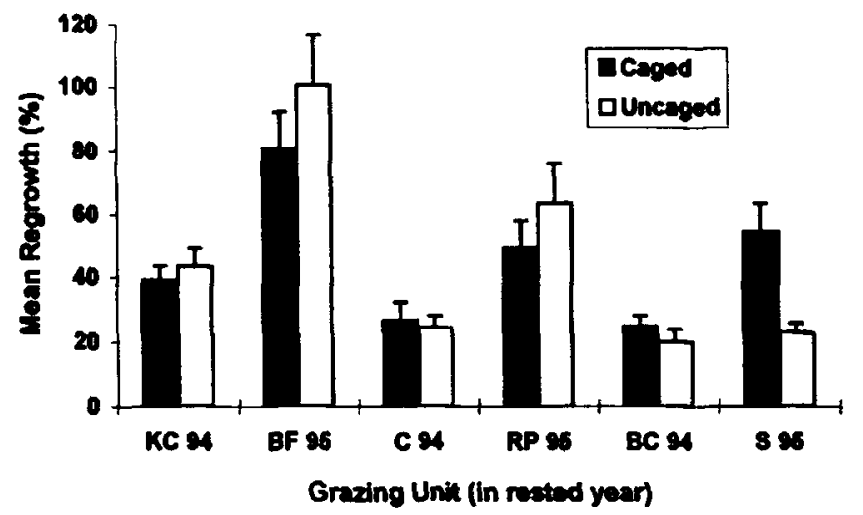

Fig. 2. Average June-to-August forage regrowth ( \pm SEM) within caged and uncaged areas on the rested units of the Koosharem (KC = Koosharem Canyon grazing unit; BF = Burnt Flat $)$, Willow Creek ( $C=$ Cove; $\mathbf{R P}=$ Ranger Pasture), and Quichupah $(B C=$ Beaver Creek; S - Skumpah) allotments during the 1994 and 1995 cattle-grazing seasons.

\section{Results}

\section{Elk Forage Utilization}

The differences of average phytomass clipped within areas protected from elk herbivory (i.e., caged) and subjected to elk use ranged from -80.0 to $2.5 \mathrm{~kg} / \mathrm{ha}$ and 142.5 to $610.0 \mathrm{~kg} / \mathrm{ha}$ within units rested from cattle herbivory during June 1994 and June-July 1995, respectively (Fig.1). Average phytomass differences during the August sampling period ranged from -127.5 to $67.5 \mathrm{~kg} / \mathrm{ha}$ in 1994 and 187.5 to $1075.0 \mathrm{~kg} / \mathrm{ha}$ in 1995 .

The average phytomass clipped within caged areas was greater than that within areas subjected to elk use in the Burnt Flat $(\mathrm{P}<$ 0.20 ) and Ranger Pasture grazing units from June-July 1995 and within the Ranger Pasture and Skumpah units in August 1995. By making phytomass differences relative to forage availability, forage utilization was 14.1 and $35.6 \%$ within the Burnt Flat and Ranger Pasture units, respectively, during June-July 1995. Forage utilization was $34.7 \%$ in the Ranger Pasture and $42.0 \%$ in the Skumpah unit during August 1995.

\section{Precipitation Trends and Forage Regrowth}

Annual precipitation data from 5 Natural Resource Conservation Service weather station facilities (located between 2,400 and 3,000 m elevation) near all sampled units were used to interpret seasonal climatic variation. The 1995 grazing season began with a relatively wet spring (i.e., approximately $4.6 \mathrm{~cm}$, or $81 \%$ more precipitation than the 1957 to 1993 spring average). Average phytomass within the Burnt Flat, Ranger Pasture, Beaver Creek, and Skumpah grazing units was greater in June-July 1995 than in June 1994. Average phytomass differences were greater in June-July 1995 than in June 1994 within the Koosharem Canyon, Burnt Flat, Cove $(P<0.10)$, Ranger Pasture, Beaver Creek, and Skumpah $(P<0.20)$ units (i.e., all sampled units).

June-to-August forage regrowth was 31.3 and $33.0 \%$ greater in 1995 than in 1994 within caged and uncaged areas, respectively (Fig. 2). Although the average June-to-August 1995 forage regrowth was greater in caged than uncaged areas on the Skumpah unit, trespass livestock within this unit may have confounded this result. June-to-August forage regrowth within caged 


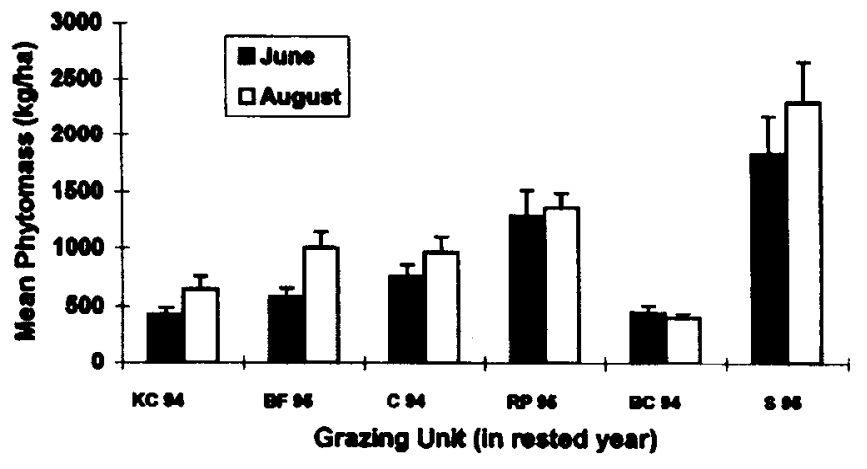

Fig. 3. Average phytomass availability ( \pm SEM) on the rested units of the Koosharem (KC = Koosharem Canyon grazing unit; $B F=$ Burnt Flat), Willow Creek ( $C=$ Cove; $R P=$ Ranger Pasture), and Quichupah (BC = Beaver Creek; S = Skumpah) allotments during the 1994 and 1995 cattle-grazing seasons.

microplots was positively associated $\left(r^{2}=0.46\right)$ with average spring phytomass differences in June 1994 and June-July 1995. Average phytomass differences for August 1994 and 1995 were also positively associated $\left(r^{2}=0.47\right)$ with the June-to-August regrowth capacity within the same microplots.

\section{Discussion}

\section{Elk Forage Utilization and Forage Regrowth}

The 1995 grazing season began with a late snow melt on the Koosharem, Willow Creek, and Quichupah allotments. Elk were observed on the spring-summer transitional range for about 3 weeks longer in 1995 than during the spring of 1994. Prolonged elk use in the spring and the relatively high forage availability (Fig.3) may account for increased forage utilization during the 1995 grazing season. Because trespass livestock were repeatedly observed within the Skumpah unit during the 1995 grazing season, the forage utilization attributable to elk may have been overestimated for this unit in August 1995.

Although average phytomass within areas protected from herbivory was greater than that within areas subjected to elk use in the Burnt Flat $(P<0.20)$ and Ranger Pasture grazing units from JuneJuly 1995 and within the Ranger Pasture and Skumpah units in August of 1995, June-to-August forage regrowth was 81, 49, and $55 \%$ within the Burnt Flat, Ranger Pasture, and Skumpah units, respectively. Thus, given the conditions necessary for regrowth, moderate defoliation during a wet season may not negate Hormay's principles regarding the restoration of plant vigor and seedling establishment via rest (Hormay and Talbot 1961).

Caldwell (1984) suggested that most photosynthetic carbon gain in plants occurs within a brief 2-month period in the spring when soil moisture and other photosyntehtic conditions are sufficient. Thus, the biological significance of elk herbivory within the rested units of the Koosharem, Willow Creek, and Quichupah rest-rotation grazing systems should be interpreted with respect to the regrowth capacity of these areas and the environmental conditions associated with plant defoliation responses.

\section{Defoliation Repsonses}

When considering plant requirements for 'prudent grazing', Caldwell (1984) suggested that foliage regrowth capacity depends on the availability of active meristemmatic tissue and the proportion of shoots and tillers with productive, photosynthetic foliage. Thus, defoliation responses depend on the intensity and timing, and environmental (e.g., moisture availability) and ecological conditions (e.g., the competitive environment) associated with the defoliation event (Trlica and Rittenhouse 1993, Briske and Richards 1994).

Defoliation intensity may be greatly ameliorated by partial reductions in competition (Mueggler 1972, 1975). Mueggler (1975) found that heavy defoliation of Idaho fescue (Festuca idahoensis Elmer) and bluebunch wheatgrass [Elymus spicatus (Pursh) Gould] (75 and 50\% herbage volume, respectively), paired with reduced competition, did not significantly reduce production in the first year post-clipping. Thus, the degree of elk herbivory during the 1995 grazing season (i.e., 14 to $42 \%$ utilization) may not reduce the short-term production within these units provided that interspecific competion is reduced via forage removal.

Moderate clipping early or late in the growing season has been shown to modestly impact the survival and vigor of grasses and forbs (Mueggler 1967, McLean and Wikeem 1985). Pearson (1964) suggested that "range grasses harvested during the period between boot stage and seed maturity [do] not recover as well as those harvested either earlier or later than this period." Flowering of dominant forage species typically occurs in July within the Koosharem, Willow Creek, and Quichupah allotments. Thus, the forage utilization observed during June (i.e., prior to the boot stage) in the Fishlake National Forest might be expected to have modest impacts on individual plant mortality, leaf height, tiller number, foliage yield, and flowering culm production (McLean and Wikeem 1985).

\section{Management Implications}

While forage utilization never exceeded the $50 \%$ 'proper use factor' prescribed by the U.S. Forest Service, it is unrealistic to assume that no elk forage utilization occurs within the rested units of our study areas. The degree of elk herbivory observed suggests that grazing management plans should address multiple, not individual, herbivore species. Moreover, by considering regrowth capacity and degree of herbivory, rangeland managers may better understand the ecological implications of herbivory relative to environmental and climatic variation.

As elk within the Koosharem allotment were observed in units with concurrent cattle use from July 1993 to July 1995 (Werner and Urness 1996), the macrohabitat selection of these herbivores is apparently influenced by a benign, rather than a competitive relationship. Cattle and elk foraging site (i.e., microhabitat) selection may be positively or negatively influenced by their interspecific interactions (Mackie 1978). Thus, we hypothesize that multiple species grazing management (e.g., elk and cattle) may be used to spatially distribute defoliation effects on individual plants and vegetational communities.

According to Lonner and Mackie (1984), management of rangelands concurrently grazed by big game and livestock should be based on the allocation of area, not forage. Rested units of rest-rotation grazing systems provide the opportunity for spatial isolation among cohabitant herbivores. Thus, the Koosharem, Willow Creek, and Quichupah rest-rotation grazing systems may 
provide an example of a "win-win" situation with respect to the economic, social, and political values associated with the rangeland resources in the Fishlake National Forest.

\section{Literature Cited}

Bonham, C.D. 1989. Measurements for terrestrial vegetation. John Wiley and Sons, N.Y.

Briske, D.D. and J.H. Richards. 1994. Physiological responses of individual plants to grazing: current status and ecological significance, $p$. 147-176. In: M. Vavra, W.A. Laycock, and R.D. Pieper (eds), Ecological Implications of Livestock Herbivory in the West, Symp. Proc.; Soc. Range Manage., Denver, Colo.

Caldwell, M.M. 1984. Plant requirements for prudent grazing, p. 117-152. In: Developing strategies for rangeland management Westview Press, Boulder, Colo.

Clegg, K. 1994. Density and feeding habits of elk and deer in relation to livestock disturbance. M.S. Thesis, Utah State University, Logan, Ut.

Frisina, M.R. 1992. Elk habitat use within a rest-rotation grazing system. Rangelands 14:93-96.

Hormay, A.L. and A.B. Evanko. 1958. Rest-rotation grazing: a management system for bunchgrass ranges. USDA For. Serv. Misc. Paper 27.

Hormay, A.L. and M.W. Talbot. 1961. Rest-rotation grazing: a new management system for perennial bunchgrass ranges. USDA For. Serv. Prod. Res. Rep. 51.

Julander, O. and D.E. Jeffery. 1964. Deer, elk, and cattle range relations on summer range in Utah. Trans. N. Amer. Wildl. and Nat Resour. Conf. 29:404-414.

Knowles, C.J. and R.B. Campbell. 1981. Distribution of elk and cattle in a rest-rotation grazing system, P. 47-60. In: J.M. Peek and P.D. Dalke (eds), Wildlife-Livestock Relationships Symposium: Proc. 10 Univ. of Idaho, Forestry, Wildlife and Range Exp. Sta., Moscow, Ida.

Lonner, T.N. and R.J. Mackie. 1984. On the naure of competition between big game and livestock, p. 53-58. In: B.F. Roache, Jr. and D.M. Baumgartner (eds), Forestland Grazing: Symp. Proc. Washington State Univ., Coop. Ext., Spokane, Wash.
Mackie, R.J. 1978. Impacts of livestock on wild ungulates. Trans. N. Amer. Wildl. and Nat. Resour. Conf. 43.462-476.

McLean, A. and S. Wikeem. 1985. Influence of season and intensity of defoliation on bluebunch wheatgrass survival and vigor in southern British Columbia. J. Range Manage. 38:21-26.

Mueggler, W.F. 1967. Response of mountain grassland vegetation to clipping in southwestern Montana.Ecology 48:942-949.

Mueggler, W.F. 1972. Influence of competition on the response of bluebunch wheatgrass to clipping. J. Range Manage. 25:88-92.

Mueggler, W.F. 1975. Rate and pattern of vigor recovery in Idaho fescue and bluebunch wheatgrass. J. Range Manage. 28:198-204.

Mueggler, W.F. 1988. Aspen types of the Intermountain region. USDA Forest Serv. Intermountain Res. Sta. Gen. Tech. Rep. INT-250.

Pearson, L.C. 1964. Effect of harvest date on recovery of range grasses and shrubs. Agron. J. 56:80-82.

Trlica, M.J. and L.R. Rittenhouse. 1993. Grazing and plant performance. Ecol. Appl. 3:21-23.

Tueller, P.T. and J.D. Tower. 1979. Vegetation stagnation in the threephase big game exclosures. J. Range Manage. 32:258-263.

Utah Division of Wildlife Resources. 1994. Utah Big Game Annual Report. Utah Dept. of Nat. Resourc.-Div. of Wildl. Resourc. Pub. No. 94-6.

Welsh, S.L., N.D. Atwood, S. Goodrich, and L.C. Higgins. 1993. A Utah flora. Brigham Young Univ. Print Services, Provo, Ut.

Werner, S.J. 1996. Elk herbivory within rested units of rest-rotation grazing systems in south-central Utah. M.S. Thesis, Utah State Univ., Logan, Ut.

Werner, S.J. and P.J. Urness. 1996. Elk herbivory, rest-rotation grazing systems, and the Monroe Mountain Demonstration Area in south-central Utah: a "seeking common ground" initiative. In: K. Evans (Comp), Sharing Common Ground on Western Rangelands: Proceedings of a Livestock/Big Game Symposium; 1996 Feb. 26-28; Sparks, Nev. Gen. Tech. Rep. INT-GTR-343. Ogden, Ut.; USDA Forest Serv., Intermountain Res. Sta.

Yeo, J.J., J.M. Peek, W.T. Wittinger, and C.T. Kvale. 1993. Influence of rest-rotation cattle grazing on mule deer and elk habitat use in eastcentral Idaho. J. Range Manage. 46:245-250. 